\title{
MONITORING AND SUPPORTING THE DEVELOPMENT OF CHILDREN AND YOUNG PEOPLE IN THE UNITED KINGDOM ${ }^{6}$
}

\section{Authors:}

Judit Tanczos

University of Debrecen

E-mail address of the first author: tanczos.judit@gmail.com

\section{Lectors:}

Magdolna Nemes

University of Debrecen

Ferenc Mező

Eszterházy Károly University

Veronika Schéder

University of Debrecen

Katalin Mező

University of Debrecen

Tanczos, Judit (2017): Monitoring and supporting the development of children and young people in the united kingdom. Különleges Bánásmód, III. évf. 2017/1. szám, 69-77. DOI 10.18458/KB.2017.1.69

\begin{abstract}
Development is a continuous process influenced by several factors. If practitioners would like to ensure children's and young persons' optimal social and emotional development and school performance, they have to monitor both development and academic achievement from early childhood until the age of 19 . In the UK, more than one million children struggle with speech, language and communication problems so the early identification is of vital importance. If identification is missed or late, it may have detrimental effects on the child's or young person's psychological, mental and physycal health. Multi-agency teams work in collaboration in order to provide the relevant help to those in need.
\end{abstract}

Keywords: factors influencing development, methods of monitoring development, SENCO, early identification of delays and disorders in language development, children in at-risk position, multi-agency approach

Disciplines: developmental psychology, pedagogy

\begin{abstract}
Absztrakt
A fejlődés egy életen át tartó folyamat, melynek menetét számos tényező befolyásolja. Ha a szakemberek biztosítani szeretnék a gyermekek és fiatalok optimális társas és érzelmi
\end{abstract}

\footnotetext{
${ }^{6}$ The editorial board does not take any responsibilty for the English of the papers. Indeed, we made some slight changes but wanted to keep the style of the authors.
} 
fejlödését, valamint iskolai teljesítményét, akkor kora gyermekkortól 19 éves korig monitorozniuk kell e folyamatokat. Az Egyesült Királyságban több mint egy millió gyermek küszködik beszéd-, nyelv- és kommunikációs problémákkal, ezért a korai azonosítás óriási fontossággal bír. Ha e problémák azonosítása késik vagy elmarad, az súlyosan károsíthatja a gyermek, illetve fiatal lelki, mentális és testi egészségét. Számos szakma képviselői együttmüködve biztosítják a megfelelő segítségnyújtást a rászorulóknak.

Kulcsszavak: a fejlődést befolyásoló tényezők, a fejlődés monitorozásának módszerei, a nyelvi fejlődés késésének és zavarainak azonosítása, veszélyeztett gyermekek, multidiszciplináris megközelítés

Diszciplína: fejlődéspszichológia, pedagógia

\section{INTRODUCTION}

Development is a continuous process which lasts throughout our life. The sequence of developmental changes is generally the same among individuals but development doesn't progress at the same rate. For example, most children utter their first words between the age of 1 and 2. Nevertheless, there are children who can say a few words already when they are 7 or 8 month old while others cannot say a word even at the age of 3 .

The knowledge of the difference between sequence and rate is important, because it has to be taken into consideration when

- $\quad$ education is planned and implemented for the different age groups

- $\quad$ education is planned and implemented for talented pupils whose rate of development at a given field can be much faster than that of the peers

- $\quad$ the practitioner meets a child whose development is delayed. The identification of the problem at an early stage enhances the chance of successful intervention.

\section{CLASSIFICATION OF FACTORS INFLUENCING DEVELOPMENT}

We can divide the factors influencing development into two main groups: these are the external and personal factors.

\section{External factors}

The most often studied external factors are poverty, family environment, abuse and care status.

\section{Poverty}

Poverty is a complex phenomenon and can hamper the development of children in multiple ways. It often leads to malnutrition, which can have a detrimental effect on the foetus (if the pregnant mother misses the right kind and amount of food) and later on the intellectual and physical development of the growing child (if they themselves are malnourished). In many cases the reason for poverty is unemployment which can strike generations within a family. If a child grows up in a family where neither the parents nor the grandparents worked ever, it will negatively influence their attitude to achievement (studying and working). The reason for unemployment is often the lack of education of the parents, which results in a less stimulating family environment for the child. It leads to additional negative consequences on the child's intellectual development. A family with a low income cannot afford to live among healthy circumstances (e. g. there may be mould in the flat, no water and electricity, etc.). It may induce illnesses, which slow down physical and intellectual development. Poverty often leads to marital problems, to alcoholism or criminal acts, which seriously damages the emotional 
development and mental health of the child. So we can see that poverty is a multiple risk factor with regard to child development. Moreover, in the majority of cases, it damages development linking together with other negative factors (health problems, negative environmental effects and unhealthy lifestyle).

\section{Family environment}

The role of family is to give love and safety and to convey the norms of socialization towards children. Family is the first medium where the learning of the rules and norms starts for the growing children. If the child's needs for love and safety are not met because of the problematic family relationships at home or if the parents convey inappropriate norms, the child's psychological and/or moral development will be negatively affected.

\section{Abuse}

There are several situations in which the child's or the young person's vulnerability can be misused. The abuse can occur in the family, at school, during outdoor programs etc. It has got different forms among which the most frequent ones are physical, emotional and sexual abuse and neglect. Any form of abuse is severely detrimental on the psychological development of children and young adults (North Yorkshire Safeguarding Children Board, n. d.).

\section{Care status}

According to research conducted among children in care status ( Kools and Kennedy, 2003), this special situation slowed down development in about $60 \%$ of the children concerned. This negative effect could be detected in several areas (e. g. in the development of language, intellectual abilities and motor skills). Generally these children had previously been traumatized before getting into care status as their placement became necessary due to their at-risk situation at home. The detachment from the family was the source of a new trauma, which adversely affected their emotional development.

Living at foster parents' have their drawbacks as well since foster children are often mocked, teased and bullied by their schoolmates. It discourages them even more and they may become outsiders or manifest challenging behaviour at school, which will impair their social development.

Beyond the four factors mentioned above, additional external factors can also influence the process of development. Seifert (n. d.) draws the attention of parents and educational practitioners to the role of media and peers. Children can see programs containing violence on the television, which may enhance their aggression and motivate them to imitate aggressive scenes. Peers have got the strongest influence on each other in adolescence and if a young person gets under the influence of a group of peers with negative values, it can be detrimental to their social and emotional development.

\section{Personal factors}

Development can be influenced by personal factors as well. The most well-known personals factors influencing development are health status, sensory impairment, learning difficulties, genetics and disabilities.

\section{Health status}

The child's actual health status can be affected by several factors. These may be inborn conditions or the onset of acute or chronic diseases. 
Foetal Alcohol Syndrome (FAS) is an example of inborn conditions, which severely effects the child's physical and mental development. If the lips and the palate are deformed, it will cause difficulties in communication, which will result in problems of social development.

In certain cases medicines taken during pregnancy can lead to birth defects. The sedative Thalidome (Human Diseases and Conditions, n. d.) caused birth defects in children whose mothers used this medicine while being pregnant in the 1950-60s. These children were born with very short and underdeveloped limbs, which severely damaged their physical development, self-esteem and the formation of social relationships.

Acute and chronic diseases can be detrimental on the health status of a child later in life as well. Diseases may have a negative impact on the child's intellectual, emotional and social development. If for example a child becomes chronically ill, they can fall behind in studying and lose their friends at school due to the changes in their lifestyles. Even short-term, acute illnesses may cause problems in achievement if they happen repeatedly.

\section{Sensory impairment}

Among sensory impairments it is the damage of vision and hearing which is detrimental to the child's development as the majority of information is perceived through these two sensory channels. Due to the impairment of sight, less information gets into the brain and the formation of coordination between the eyes and hands delays, which have negative consequences on development. Poor hearing may slow down the development of speech and communication, which leads to additional problems: delayed language development negatively affects cognitive development and the formation of social relationships, that is it hinders social development.

\section{Learning difficulties}

If a child's intellectual abilities are intact, the reason for their poor achievement at school may be learning difficulties (e. g. dyslexia, dysgraphia or dyscalculia), dyspraxia or ADHD. The child is hindered by these conditions and will be an underachiever until he gets adequate support. The consequences of the missed or late identification of learning difficulties may be extremely severe to the personal, emotional and social development of the child and may impede their academic achievement and choice of career.

\section{Genetics}

Genetic disorders may impede several areas of development. A well-known chromosomal abnormality is Down syndrome. It causes mental retardation and deviations in speech development. Additional health problems can often be diagnosed, such as special malformations on the face and the tongue, heart failure, decreased muscle tonus etc. (First Signs, n. d.).

\section{Disabilities}

Disabilities can severely impair the child's physical and/or intellectual development depending on the type of the impairment (physical, learning or both). In addition to it, disability can have detrimental effects on the child' emotional and social development as well, e. g. the child cannot socialize with peers as often as it would be desirable or they can be mocked and bullied by other children, which can have an extremely harmful effect on their self-esteem and mental health. The cultural background of the disabled child may also influence the attitudes of the family members towards the child, which can either compensate or strengthen the negative effects mentioned beforehand. There are several developmental disorders which can lead to disability. As indicated by First Signs (n. d.), the most frequent 
developmental disorders in order of priority among schoolchildren in the US are the following: mental retardation, cerebral palsy and autistic spectrum disorder.

Mental retardation

The intellectual abilities of children suffering from mental retardation are below the average. This disability severely damages cognitive development and has a negative impact on the formation of social relationships, learning, choosing profession and starting to live independently.

Cerebral palsy

This is a neurological condition which primarily impairs the development of motor skills but it has a negative influence on the development of speech and of visual and auditive perception as well. Depending on the extent of the damage, the child or young person suffering from cerebral palsy can be limited in their movement only moderately but they can become severely disabled as well.

Autistic spectrum disorder

According to The National Autistic Society (n. d.), autism is a developmental disorder which is severely detrimental on the development of social relationships and communication. It also impairs perception and can cause learning disabilities. It may have mild and severe forms. People with severe forms of autism are unable to live independently.

Beyond the disabilities mentioned above, spina bifida is a developmental disorder often studied. It hampers primarily the gross motor skills as it may lead to the weakening or even the total paralysis of the legs. In most cases spina bifida doesn't affect cognitive development but if it is associated with hydrocephalus, it can lead to learning difficulties. This developmental disorder also causes certain health problems for example urinary and bowel incontinence (NHS choices, n. d.).

\section{An explanation of how to monitor children and young people's development using different methods}

If practitioners would like to ensure children's and young persons' optimal social and emotional development and school performance, they have to monitor both development and academic achievement from early childhood until the age of 19.

According to Southern Early Childhood Association (2000), monitoring methods can be divided into two groups: there are formal and informal methods. Formal methods are more settled and regulated. They are executed with the application of standardized tests within predetermined circumstances. The child's results can be compared to the results of others in the same age group. Examples of formal methods are assessment tests, intelligence and diagnostic tests etc. Informal methods are less strictly regulated and predetermined. They involve e. g. the different types of observational methods and the collection of children's work samples (drawings, paintings, samples of handwriting etc.)

We can classify monitoring methods according to the school setting where they are applied. There are methods that can be used both in primary and secondary schools, e. g. formative and summative assessment, peer assessments, SATS (Standard Assessment Tests) and observations. But 11-plus is applied only on primary level while CATs (Cognitive Ability Tests) and GCSE are used only on secondary level.

The most frequently used formal monitoring methods are formative and summative assessment. 
Formative assessment enables teachers to trace the child's academic progress throughout the whole school-year. Its advantage is that it gives the possibility for the early identification of problems (e. g. formal test writing). In contrast, summative assessment evaluates learning only at the end of the school-year. It shows whether the child has reached their previously determined academic goals. The results of both methods are highly informative for the pupils, the teachers and the parents as well.

Among the informal methods, it is observations which are the most often applied for monitoring.

During observations the practitioner observes a child's activities (behaviour, leisure activities, playing, studying etc.) in different situations. The main types of observation methods are the following:

Time sampling: we divide a certain amount of time into intervals with equal length and record at the end of each interval whether the given behaviour has or has not happened. The aim is to identify the possible problem(s). Its advantage is that we can see the frequency of the behaviour so we can decide whether our preoccupation was right or not (Project PARA, n. d., Department of Education and Skills Standard Unit, 2005).

Event sampling: Whenever a predetermined behaviour occurs within a certain period of time (e. g. a week), we record the event. It shows the frequency of the given behaviour. a special type of this method (the ABC Chart) is suitable for exploring the antecedents as well. In the possession of the information, we can plan the modification of the problematic behaviour e. g. by ceasing the causes which triggered it (Department of Education and Skills Standard Unit, 2005).

Free narrative: In a certain period of time, we observe everything in detail and record the events and behaviours as they happened one after the other. Generally we make the observation because of a special reason. The advantage of the method is that it helps to understand the context of the behaviour, too.

Target child observation: It is similar to free narrative but with the help of this method, we observe a particular child within a given period and record everything related to him in detail (their behaviour, interactions, verbal and nonverbal communication etc.).

Anecdotal record: It is the detailed follow-up recording of a particular event related to a given child. We focus only on the behaviour we are concerned about. If we make anecdotal records several times subsequently, it is suitable for the tracing of the development of the given child (Project PARA, n. d.).

\section{An explanation of how different types of interventions can promote development}

There are several ways to help a child if their development fails to follow the expected pattern. Practitioners of different fields work together applying a multi-agency approach in supporting children and young persons struggling with developmental issues. They collaborate with the parents as well, providing them with detailed information about the problem and with advice on how to take part in the support or therapy of their child. Practitioners working outside the school setting are in constant relationship with the given child's teachers, teaching assistants and the SENCO (Special Educational Needs Coordinator), providing them with help and guidance in the planning and implementation of intervention.

The process of intervention is the following: if a teacher or a teaching assistant have concerns about a child's development, they ask for the help of the SENCO, who is responsible for children with special educational needs within the school setting. The SENCO will get in touch with the professionals of different agencies and services whose intervention is relevant in the given situation. The SENCO has a main role in the coordination of the efforts of the school staff, of the professionals working in the multidisciplinary team and of the parents. 
Depending on the child's problem, the intervention of the following professionals can promote development most effectively:

- Speech, language and communication problems: speech and language therapists (SLT)

- Physical health issues (e. g. diabetes, asthma etc.): health visitors (for children between the age of 0 to 5 ) or nurse specialists (for older children)

- Mental health issues: psychiatrists

- $\quad$ Learning or behaviour problems: educational psychologists

- $\quad$ Problems of gross motor skills (e. g. cerebral palsy, spina bifida): physiotherapists

- $\quad$ Social care problems (e. g. difficult home situations, care status): social workers

- $\quad$ Being at risk of exclusion (e. g. vulnerable children): youth justice workers.

An analysis that shows the importance of early identification of speech, language and communication delays and disorders, and the potential risks of late recognition

According to the Royal College of Speech and Language Therapists (2007), communication disorders are the most frequent disorders in early childhood. Approximately $10 \%$ of the children struggles with speech, language and communication problems in the UK, which means more than 1 million children (The Communication Trust, 2012). As identified by the American Speech -Language- Hearing Association (n. d.), the early signs of these problems are the following: a, the child hasn't started to speak by the age of one, $b$, the speech is not clear and c, the child's speech is not similar to that of the children of the same age.

The early identification of speech, language and communication problems is of vital importance, the earlier they are recognized, the more effective their treatment can be. Early recognition and treatment can prevent the damage of development caused by the unsolved language disorders.

As stated by the American Speech -Language- Hearing Association (n. d.), the identification of the disorders can take place even under the age of three in the following cases:

$a$, in the case of children showing the symptoms of disturbed language development or $b$, in the case of at-risk children whose speech, language or communication development may delay or who have a disability related to these areas of development. Children especially being in at-risk position are:

- premature infants

- $\quad$ children with biological factors (e. g. FAS syndrome)

- $\quad$ children with genetic disorders (e. g. Down syndrome)

- $\quad$ children with medical conditions (e. g. asthma, recurrent ear inflammations)

- $\quad$ children with neurological conditions (e. g. cerebral palsy).

However, if the child's problem remains unrecognized and the child doesn't get the appropriate help until the age of five, it will result in the severe impairment of written and spoken language in most cases. At one-third of those who struggle with difficulties in communication, some mental illness will also develop after a time. Due to communicational problems and mental illness, these children or young persons will often become outcasts and commit criminal acts (Royal College of Speech \& Language Therapists, 2007).

The vast majority of children with learning disability have speech, communication and language problems. The late identification of the learning disability and the language development disorder may lead to severe negative consequences. The child's lagging behind at school slows down their cognitive development, the parents and the teachers are discontented and disappointed with the child's school performance, which leads to loss of self- 
esteem, anxiety and anger in the child. Poor achievement at school will impede the young person's entering into high school or choosing the adequate profession. Due to these failures the young person's personality development may take a negative direction and it may lead to antisocial or self-destructing behaviours such as aggression, offending the law or drug abuse (Dyslexia International, n. d.).

These findings clearly show the importance of early identification and intervention. If identification is missed or late, it may have a detrimental effect on the child's or young person's

- $\quad$ intellectual development (as language and thinking develops in interaction with each other)

- emotional and social development (communication problems lead to disruptions in social relationships, which results in serious emotional problems)

- $\quad$ lagging behind at school, which hinders the progressing to secondary school, choosing vocation and getting a job

- $\quad$ mental and physical health (due to the problems mentioned beforehand, mental illness and drug addiction can develop).

\section{An explanation of how multi-agency teams work together to support speech, language and communication}

Multi-agency working is a holistic approach of supporting children and young persons struggling with speech, language and communication problems. It is the collaboration of different services, agencies and experts who work together in order to provide the relevant help to those in need.

The multidisciplinary team consists of professionals from the educational, health and social care sector. If it is necessary, experts of the criminal justice sector can also participate in the work. Every multi-agency team has a leader, the so called lead professional who coordinates the work and with whom the child and their parents can maintain the relationship (Meggitt et al., 2012, p. 216). The key person of the team is the Speech and Language Therapist who cooperates with

- $\quad$ clinicians, health visitors and nurses (health care)

- $\quad$ nursery and school teachers, nursery and teaching assistants, SENCO (education)

social workers (social care), etc. (Royal College of Speech \& Language Therapists (2007).

These professionals come together, share the information related to the given child's case and plan the methods and steps of intervention, in which the role of each professional participant is established. During their collaboration, they regularly discuss their experiences, evaluate progress and support each other's work in order to solve the child's speech, language and communication problem and promote their mental health and emotional well-being. They also maintain the relationship with the child's parents or even ask them to participate actively in the child's therapy (C4EO, n. d.).

Since 2012, multi-agency working for supporting children and young people with speech, language and communication problems has been greatly enhanced by The Communication Trust in the UK. It is a coalition of almost 50 voluntary organizations and advisory groups working on this area (The Communication Trust, 2012).

\section{SUMMARY}

Human development is a complicated and complex process. Several factors can influence this process by fastening, slowing down or even temporarily stopping it. The knowledge of these factors is essential for professionals working with children and young adults as it 
provides the necessary theoretical basis to the successful support of the development of the young generation. By using different monitoring methods, practitioners can ensure children's and young persons' optimal social and emotional development and school performance. If intervention is needed, multi-agency teams work together and provide the relevant help to solve the problem.

\section{REFERENCES}

American Speech -Language- Hearing Association (n. d.) Early Identification of SpeechLanguage Delays and Disorders http://www.ldonline.org/article/6231/ (Download: 24.03.2015)

C4EO (n. d.) Early Intervention. (Download: 25.03.2015). (Web: http://archive.c4eo.org.uk/themes/earlyintervention/vlpdetails.aspx?lpeid=46).

Department of Education and Skills Standard Unit (2005) Observation Booklet 7c (Download:

29.03.2015).(Web:http://tlp.excellencegateway.org.uk/resource/SHD_6013Q/screens/down loads/booklet_7c.pdf).

Dyslexia International (n. d.) The Problem. (Download: 24.03.2015). (Web:http://www.dyslexia-international.org/the-problem/).

First Signs (n. d.) Other Developmental and Behavioral Disorders (Download: 12.03.2015). (Web: http://www.firstsigns.org/delays_disorders/other_disorders.htm).

Human Diseases and Conditions (n. d.) Birth Defects (Download: 12.03.2015). (Web: http://www.humanillnesses.com/original/At-Ca/Birth-Defects.html).

Kools, S., Kennedy, C. (2003) Foster Child Health and Development: Implications for Primary Care. Pediatric Nursing 29(1) (Download: 12.03.2015). (Web: http://www.medscape.com/viewarticle/449673_4).

Meggitt, C., Bruce,T., Grenier, J. (2012) Child Care and Education. Second Edition. London: Hodder Education, An Hachette UK Company.

NHS choices (n. d.) Spina bifida (Download: 17.03.15). (Web: http://www.nhs.uk/conditions/Spina-bifida/Pages/Introduction.aspx).

North Yorkshire Safeguarding Children Board (n. d.) What is child abuse? (Download:12.03.2015). (Web: http://www.safeguardingchildren.co.uk/section-1.html).

Project PARA (n. d.) Observation Techniques (Download: 29.03.2015). (Web: http://para.unl.edu/legacy/Observation/lesson4.php).

Royal College of Speech \& Language Therapists (2007) Speaking out: early intervention for young children with communication difficulties (Download: 24.03.2015) (Web: http://www.speech.derbys.nhs.uk/documents/RCSLTPaliamentaryflyer3.pdf).

Seifert, C. (n. d.) How Children's Development Is Influenced by External Factors (Download 12.03.2015). (Web: http://everydaylife.globalpost.com/childrens-development-influencedexternal-factors-6727.html).

Southern Early Childhood Association (2000) Assessing Development and Learning in Young Children (Download: 27.03.2015). (Web: http://www.southernearlychildhood.org/upload/pdf/Assessing_Development.pdf)

The Communication Trust (2012) Cracking Communication November 2012 Workshop Sessions (Download: 27.03.2015). (Web: http://www.thecommunicationtrust.org.uk/aboutthe-trust/previous-projects/conference/november-2012-workshop-sessions/).

The National Autistic Society (n. d.) What is autism? (Download: 16.03.2015). (Web: http://www.autism.org.uk/about-autism/autism-and-asperger-syndrome-anintroduction/what-is-autism.aspx). 